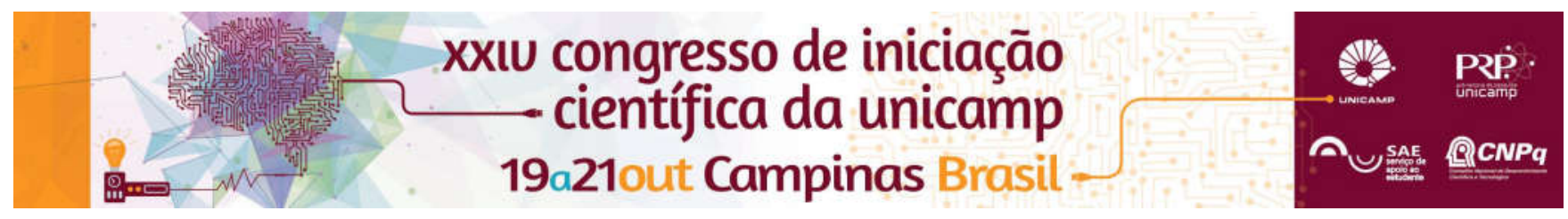

\title{
Nutrientes em águas estuarinas como indicadores de atividades de indústrias de fertilizantes
}

\author{
Heitor B. Roloff*, Wanilson Luiz-Silva, Wilson Machado, Alice Bosco-Santos
}

\section{Resumo}

Concentrações de nutrientes em águas estuarinas da Baixada Santista (SP) foram investigadas durante um ciclo de maré e em várias profundidades. Os resultados mostraram incremento nos níveis de fosfato e silicato com a diminuição da salinidade, e forte relação de fonte de nutrientes com atividades industriais.

Palavras-chave: Poluição, nutrientes, estuários.

\section{Introdução}

O sistema estuarino de Santos-Cubatão (SESC), São Paulo, abriga um dos maiores polos industriais da América Latina, o qual inclui fábricas de fertilizantes fosfatados, potenciais fontes de nutrientes para as águas estuarinas. A eutrofização representa um risco ao equilíbrio da cadeia alimentar nesses ambientes, à medida que o excesso de nutrientes, como os compostos ricos em fósforo, gera um aumento das populações de algas. Estas ocasionam o aumento dos consumidores primários e, portanto, um maior consumo de oxigênio, diminuindo seus teores dissolvidos na água, provocando morte e decomposição de muitos organismos. O objetivo deste estudo foi analisar as concentrações de fosfato e silicato em águas do SESC e identificar suas relações com fontes antrópicas presentes na área.

\section{Métodos}

Foram coletadas águas de superfície em um único ciclo de maré (agosto/2015) em sete pontos distribuídos nos estuários dos rios Morrão (setor mais à montante da influência marinha e mais próximo às indústrias), Quilombo, Cubatão, Largo do Caneu, Casqueiro e Branco, além do Mar Pequeno (setor mais próximo à Baia de Santos e distante das indústrias). As amostras foram coletadas no topo, meio e fundo dos canais estuarinos, nas marés vazante e cheia. Parâmetros físico-químicos foram medidos in situ e as amostras foram filtradas $(0,22 \mu \mathrm{m})$ e analisadas (fosfato e silicato dissolvidos) por espectrofotometria UV-vis (APHA, 1992).

\section{Resultados e Discussão}

Os resultados do estudo estão na Tabela 1. Em geral, o $\mathrm{pH}(7,4 \pm 0,2)$ e Eh $(457 \pm 11 \mathrm{mV})$ foram uniformes (médias) em todos os locais de coleta, profundidade da lâmina d'água e regimes de maré. A salinidade e os conteúdos de fosfato $(7,07$ a $0,72 \mathrm{mg} / \mathrm{L})$ e silicato $(7,86$ a $0,96 \mathrm{mg} / \mathrm{L})$ mostraram uma tendência de diminuição à medida que o ponto amostral se aproximou do oceano (Baía de Santos). Coeficientes de correlação negativos entre salinidade-fosfato e salinidade-silicato $(r \sim-0,61)$ mostraram a maior influência de aportes continentais no incremento dos níveis destes nutrientes. Notadamente, os valores destas variáveis foram maiores na maré vazante (Tabela 1), durante a qual incrementaram com a profundidade da lâmina d’água. Isso foi resultado da cunha salina mais densa no fundo em contraste com o fluxo de águas continentais na superfície. Esse gradiente também se repetiu durante a maré cheia, porém com menor intensidade devido ao baixo contraste da estratificação salina na coluna d’água neste episódio de maré.

Relação entre a proximidade de indústrias de fertilizantes fosfatados e os níveis de fosfato e sílica na água foi verificada, e correlação positiva $(r=0,70)$ sugere origem comum. No rio Morrão, que está na área de influência de indústrias de fertilizantes, os níveis de fosfato e silicato foram os mais altos. Em contraste, o Mar Pequeno, o mais distante de áreas industriais, mostrou níveis de nutrientes bem inferiores (Tabela 1). Assim, os resultados indicaram que as águas do SESC apresentaram níveis elevados e contrastantes de nutrientes que podem desencadear o processo de eutrofização (Braga et al. 2000). Em adição, o SESC funciona como um exportador de nutrientes, possivelmente de origem antrópica, para a Baía de Santos, cujas consequências necessitam ser investigadas futuramente.

Tabela 1. Parâmetros físico-químicos e concentrações de fosfato e silicato (valores médios, $N=3$ ) em águas estuarinas nas marés vazante (MV) e cheia (MC), em função da distância das indústrias.

\begin{tabular}{|c|c|c|c|c|c|c|}
\hline & Locais & $\mathrm{pH}$ & Eh $(\mathrm{mV})$ & Salinidade & $\begin{array}{c}\begin{array}{c}\text { Fosfato } \\
(\mathrm{mg} / \mathrm{L})\end{array} \\
\end{array}$ & $\begin{array}{l}\text { Silicato } \\
(\mathrm{mg} / \mathrm{L})\end{array}$ \\
\hline \multirow{9}{*}{ 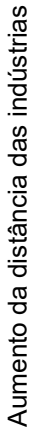 } & Morrão (MV) & 7,2 & 455 & 21,9 & 7,07 & 7,86 \\
\hline & Morrão (MC) & 7,5 & 455 & 31,2 & 4,03 & 5,33 \\
\hline & Quilombo (MV) & 7,1 & 471 & 23,3 & 5,51 & 4,83 \\
\hline & Quilombo (MC) & 7,5 & 465 & 31,7 & 3,57 & 2,58 \\
\hline & Cubatão (MV) & 7,3 & 461 & 26,1 & 3,45 & 4,52 \\
\hline & Cubatão (MC) & 7,5 & 456 & 32,1 & 2,48 & 3,42 \\
\hline & Caneu (MV) & 7,5 & 443 & 31,5 & 2,27 & 0,96 \\
\hline & Caneu (MC) & 7,7 & 431 & 34,0 & 2,11 & 2,48 \\
\hline & Casqueiro (MV) & 7,5 & 462 & 29,8 & 2,01 & 3,17 \\
\hline \multirow{5}{*}{$\downarrow$} & Casqueiro (MC) & 7,7 & 470 & 33,1 & 1,92 & 4,03 \\
\hline & Branco (MV) & 7,2 & 465 & 25,1 & 0,98 & 4,04 \\
\hline & Branco (MC) & 7,5 & 460 & 30,8 & 1,05 & 3,90 \\
\hline & Mar Pequeno (MV) & 7,2 & 455 & 29,3 & 1,14 & 1,24 \\
\hline & Mar Pequeno (MC) & 7,6 & 446 & 32,5 & 0,72 & 3,23 \\
\hline
\end{tabular}

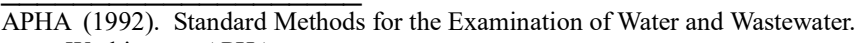
Washington: APHA.

Braga, Braga, E. S. et al. (2000). Eutrophication and bacterial pollution caused by industrial and domestic wastes at the Baixada Santista estuarine system - Brazil. Marine Pollution Bulletin, 40: 165-173. 